ARTIKEL

Filsafat Politik Nurcholish Madjid

Muhammad Saleh Tajuddin

Kedaulatan Rakyat dalam Pemikiran Filsafat

Politik Montesquieu

Fajrul Ilmy Darussalam \& Andi Batara Indra

$189-204$

Politik Multikulturalisme: Sebuah Gerakan Keadilan

dan Kesetaraan

Muhaemin Latif

$205-229$

Kompetisi, Kompromi dan Coalition Agreement: Berebut

Kursi Wakil Gubernur DKI Jakarta di Tengah

Kontestasi Pemilihan Presiden 2019

Mahpudin \& Fransisca Mega Lestari

$230-259$

Kegagalan Keterlibatan Politik: Dari Kesenjangan Digital

Menuju Kesenjangan Demokrasi

Fairuz Arta Abhipraya \& Bambang Eka Cahya Widodo

Mobilisasi Massa Kemenangan Kolom Kosong Pada Pemilihan Walikota Makassar Tahun 2018

Gustiana Kambo

Kinerja Komisi Pemilihan Umum Kota Makassar dalam

Melindungi Hak Pilih Warga di Tengah

Pandemi COVID-19

Dyahwanti Sulistyowati, Muhammad, Sukri \& Ariana

Isu Pemekaran Wilayah Sebagai Komoditas Politik Dalam Masyarakat

To Pulo di Kepulauan Selayar

Dwi Indriani \& Sudarmono

Penanganan Konflik Melalui Keamanan di Kalimantan Barat 


\title{
POLITIK MULTIKULTURALISME: SEBUAH GERAKAN KEADILAN DAN KESETARAAN
}

\author{
Muhaemin Latif \\ UIN Alauddin Makassar \\ Email: muhaemin.latif@uin-alauddin.ac.id
}

\begin{abstract}
Abstrak
Politik multikulturalisme adalah upaya pemberian kesempatan yang setara kepada setiap penduduk untuk berpartsipasi pada ruang-ruang publik dalam suatu komunitas atau masyarakat. Dua elemen penting yang harus menjadi fondasi dalam mengimplementasikan politik multikulturalisme adalah keadilan dan kesetaraan. Artikel ini mendiskusikan politik multikulturalisme sebagai sebuah diskursus penting dalam disiplin sosial dan politik. Multikulturalisme tidak hanya sekadar sebagai wacana yang berakhir dalam tataran teoretis, tetapi ia menjelma sebagai ideologi dalam melakukan perubahan sosial dan politik terutama dalam mengelola perbedaan. Jenis penelitian yang yang dipergunakan dalam artikel ini adalah kualitatif dengan penekanan pada kajian kepustakaan. Peneliti menelusuri referensi-referensi yang berkaitan langsung dengan tema politik multikulturalisme yang ditulis langsung oleh para tokoh-tokoh yang selama ini dikenal sebagai pakar multikulturalisme. Data-data tersebut kemudian dikategorisasi berdasarkan tema-tema politik multikulturalisme seperti rasisme dan culture studies. Peneliti berkesimpulan bahwa multikulturalisme tidak cukup hanya dilihat sebagai sebuah kontestasi perbedaan tetapi perbedaan itu harus dirayakan dalam bentuk aksi atau gerakan. Politik multikulturalisme berpijak kepada gerakan keadilan dan kesetaraan terhadap budaya, ras, bahasa, bahkan agama.
\end{abstract}

Kata Kunci:

Politik, Multikulturalisme, Rasisme, Kewarganegaraan, Pengakuan

\begin{abstract}
Politics of multiculturalism is an effort to provide a space for the citizens to participate same opportunity in servicing people to fulfill their interests particularly in public spaces. There are two important element that should be considered are justice and equality. The article discusses the politics of multiculturalism as an important discourse in the field of social and politics discipline. Multiculturalism is not only a contested issue which concern on theoretical concept, but more importantly it is strongly associate with the ideology that can change sosial and political inequality particularly regarding diversities. The author employed a qualitative research methodology focusing library research. To obtain data, the author explored a number of references related to multiculturalism which were written by recognized scholars. The data then categorized based on the politics of multiculturalism themes supported by racism materials and culture studies. The author concludes that politics of multiculturalisme should not only regarded as the issue of differences but also it is a celebration of diversities. Politics of multiculturalisme can generate an action which encourages a movement for change in social inequality.
\end{abstract}




\section{Keywords: \\ Politics, Multiculturalism, Racism, Citizenship, Recognition}

\section{Pendahuluan}

Terminologi multikulturalisme telah menjadi issu penting dalam dunia ilmuilmu sosial politik dalam kurun waktu 1980-an dan 1990-an. Kemunculan istilah ini tidak bisa dilepaskan dari munculnya berbagai konflik antar etnis budaya yang terjadi di berbagai belahan dunia mulai dari Amerika sampai di daratan Eropa. Bahkan istilah multikulturalisme tidak hanya booming di dua benua tersebut, Asia juga tidak luput dari pembicaraan multikulturalisme. Faktor dominasi satu etnis budaya yang cenderung menghegemoni budaya lainnya, pertarungan antara segmen mayoritas dan minoritas pada satu negara serta pertaruhan klaim sebagai penduduk asli (indigenous) dan stigma pendatang setidaknya menjadi bagian dari pemicu kemunculan konflik tersebut. Faktorfaktor ini akan terus muncul jika perbedaan-perbedaan ras, etnis dan agama tidak dikelola dengan baik. Karena sejatinya perbedaan itu menjadi sesuatu yang natural dalam kehidupan manusia. Dengan kata lain, usaha untuk menyatukan keragaman tersebut adalah usaha yang berkesinambungan dan tidak akan pernah berakhir (endless project).

Berbagai teori yang muncul untuk menjadi obat penawar dalam menangani konflik tersebut telah dimunculkan oleh kalangan intelektual. Sebutlah teori melting $\operatorname{pot}^{1}$ yang muncul di Amerika oleh J. Hector, seorang imigran asal Nomandia. Ia mengatakan bahwa beragam suku yang berbeda-beda yang masing-masing merepresentasikan budaya dan identitas yang berbeda bisa dilebur menjadi satu identitas sehingga ragam identitas tersebut tidak lagi menyeruak di atas perbedaan-perbedaan tersebut. Hector mencontohkan bagaimana identitas "Amerika" menjadi satu-satunya identitas yang muncul dalam negara Amerika mengalahkan identitas-identitas lainnya. Identitas-identitas seperti White Anglo Saxon, Black African, Hispanik yang hidup di negara Amerika tidak lagi menjadi identitas yang muncul di ruang-ruang publik dalam hubungan kewarganegaraan mereka semua dipersatukan dalam satu payung besar "Amerika".

${ }^{1}$ Istilah melting pot ini pertama kali ditemukan dalam tulisan J.Hector St John de Crevecouer dalam Letters from an American Farmer (1782). 
Hanya saja, teori melting pot ini ternyata tidak mampu memberikan kepuasan bagi setiap orang Amerika. Dengan kata lain, teori ini dianggap gagal mempersatukan perbedaan atau keragaman di kalangan warga Amerika. Justru yang terjadi adalah kepincangan antara berbagai etnis di kalangan internal mereka. Gesekan-gesekan antar etnis atau budaya tersebut seringkali mewarnai sejarah Amerika itu sendiri, terutama antara warga Amerika kulit putih (White Anglo Saxon) dan black American. ${ }^{2}$

Kondisi di atas pernah diceritakan oleh Condoleezza Rice (mantan Menteri Luar Negeri Amerika) bahwa sekitar 1960-an, adanya segregasi pelayanan bus antara kulit putih dan kulit hitam masih terjadi di Amerika. Bus yang dikhususkan untuk masyarakat kulit putih tidak boleh diisi oleh masyarakat kulit hitam dan begitupula sebaliknya. Artinya, bukan hanya manusianya yang menjadi obyek segregasi, tetapi fasilitasfasilitas umum seperti sarana transportasi, sekolah, tempat-tempat wisata pun tidak luput dari segregasi. Fakta-fakta ini mendemonstrasikan bahwa problem keragaman dan perbedaan masih menjadi ancaman di berbagai negara terlepas apakah negara tersebut dikategorikan sebagai negara maju, berkembang, apalagi negara yang masuk dalam kategori miskin. Kondisi inilah yang melanda negara-negara Afrika yang sampai sekarang ini masih terus dilanda kekacauan konflik internal akibat perbedaan antara suku yang sangat sulit untuk disatukan.

Setelah teori melting pot dianggap gagal untuk menangani dan mengelola keragaman di Amerika, maka muncullah teori salad bowl yang diharapkan bisa menjadi solusi keragaman. Teori ini sendiri pertama kali dimunculkan dan dipopulerkan oleh Horace Kallen, seorang filosof Amerika. Teori ini relatif berbeda dengan melting pot yang meleburkan atau menghancurkan semua identintas menjadi satu identitas tunggal. Salad bowl adalah teori yang tidak berusaha melebur atau menghancurkan berbagai identitas tersebut tetapi membiarkan identitas-identitas itu hidup dengan sendirinya. ${ }^{3}$ Dengan kata lain, identitas yang berbeda itu tidak dinegasikan eksistensinya bahkan mendapat pengakuan baik dari sesama budaya ataupun dari pemerintah.

Poin yang disebut terakhir inilah yang menjadi poin sentral dari mutikulturalisme. Pengakuan menjadi sesuatu yang essensial dalam wacana

\footnotetext{
${ }^{2}$ Akhyar Yusuf Lubis, Pemikiran Kritis Kontemporer: Dari Teori Kritis, Culture Studies, Feminisme, Post-Kolonial hingga Multikulturalisme (Jakarta: Raja Grafindo Persada, 2015), h. 174.

${ }^{3}$ Ibid., h. 172.
} 
multikulturalisme. Tanpa pengakuan atau rekognisi, maka pembicaraan multikulturalisme mengalami kebuntuan. Disinilah perbedaan antara pluralisme dan multikulturalisme, kalau pluralisme masih berkutat pada penghormatan terhadap perbedaan antar budaya yang berbeda, maka multikulturalisme melampaui gagasan tersebut, konsep ini tidak hanya menghormati tetapi meletakkan pengakuan sebagai titik sentralnya. Dalam perkembangannya, multikulturalisme tidak bisa dilepaskan dari tiga orientasi, yaitu sebagai ideologi, issu sosial dan wacana akademik. ${ }^{4}$ Politik multikulturalisme pada artikel ini tampaknya berkaitan dengan multikulturalisme sebagai ideologi yang dijadikan sebagai bahan untuk menggerakkan masyarakat secara politik. Karena sifatnya ideologi, maka multikulturalisme menjadi satu alasan bagi kelompok-kelompok sosial kemasyarakatan untuk melawan ketidakadilan sosial dan diskriminasi. Atas nama persamaan hak sebagai sesama warna negara, ideologi multikulturalisme telah berhasil merubah tatanan sosial politik yang tidak berpihak kepada seluruh masyarakat. Artikel ini akan memotret politik multikulturalisme sebagai sebuah gerakan keadilan dan kesetaraan. Dalam penerapannya, politik multikulturalisme akan beririsan dengan issu-issu rasisme dan gerakan-gerakan budaya yang seringkali menjadi sasaran dari ketidakadilan. Bahkan istilah politik multikulturalisme tidak bisa dilepaskan dari terminologi politik rasisme dan politik budaya. Dengan kata lain, politik multikulturalisme diibaratkan sebagai payung besar yang mewadahi hadirnya politik rasisme dan politik budaya. Tema-tema tersebut akan menjadi pembahasan penting dalam artikel ini.

\section{Metode Penelitian}

Jenis penelitian yang dipergunakan dalam artikel ini adalah kualitatif. Peneliti menfokuskan kepada kajian kepustakaan dengan menelusuri sumber-sumber primer yang terkait dengan multikulturalisme serta hubungannya dengan politik. Sumbersumber tersebut sebagian besar berasal dari jurnal-jurnal internasional, buku, serta informasi-informasi dari internet yang memuat informasi-informasi obyektif tentang praktek multikulturalisme di berbagai negara. Data-data yang terkumpul kemudian dikategorisasi serta dianalisis dengan menggunakan metode content analysis (analisis

${ }^{4}$ Malory Nye, "The Challenges of Multiculturalism" dalam Culture and Religion, Vol. 8, No. 2 (2007), h. 109-123. 
isi). Setelah data-data tersebut dikelompokkan berdasarkan tema, peneliti membandingkan dan mencari benang merah antara satu data dengan data-data yang lain sehingga bisa memunculkan pernyataan-pernyataan yang bersifat obyektif.

\section{Politik Multikulturalisme}

Secara umum, politik multikulturalisme bisa dimaknai sebagai pemberian kesempatan yang sama kepada setiap warga negara untuk merepresentasikan identitasnya di ruang-ruang publik terlepas dari berbagai perbedaan baik terkait ras, suku, agama dan bahasa. Dengan kata lain, politik multikulturalisme menfokuskan kepada dua hal penting yaitu perbedaan dan kesetaraan. ${ }^{5}$ Dua hal ini menjadi fondasi dalam menjelaskan dan mengimplementasikan politik multikulturalisme.

Politik multikulturalisme tidak hanya menyentuh lapisan teoretis, tetapi berusaha melakukan perubahan-perubahan sosial baik dari aspek regulasi maupun dari aspek kebijakan publik. Dengan kata lain, arena politik multikulturalisme melekat pada aksiaksi sosial yang biasanya dilakoni oleh warga yang secara politik mengalami ketidakseimbangan atau turbulensi. Politik multikulturalisme marak terjadi di negaranegara yang secara kultural memang mengalami perjumpaan-perjumpaan, terutama antara penduduk asli dan para pendatang (imigran), kulit hitam versus kulit putih serta bahasa asli dan bahasa pendatang.

Terkait dengan politik multikulturalisme yang menyasar pada aspek perbedaan bahasa. Kasus yang terjadi di Quebec, Kanada pada tahun 2013 menarik untuk dijadikan sebagai sampel dalam konteks ini. Sebagaimana diketahui bahwa Quebec, Kanada adalah warisan kolonialisme Perancis. Faktor inilah yang membuat masyarakat Quebec masih dipengaruhi oleh budaya Perancis, terutama dari aspek bahasanya. Khusus masyarakat Quebec, mereka bangga dengan bahasa Perancis yang mereka gunakan sehari-hari. Hal ini bukan berarti bahwa mereka tidak paham bahasa Inggris. Hanya saja, mereka lebih bangga dengan bahasa Perancis nya dibandingkan dengan bahasa Inggris. Sementara di sisi lain, Kanada yang berbatasan secara geografis dengan Amerika, pengaruh bahasa Inggris juga tidak bisa dinegasikan. Bahkan beberapa daerah di Kanada hampir semuanya berbahasa Inggris, kecuali Quebec.

${ }^{5}$ Heru Nugroho, "Multikulturalisme dan Politik anti Kekerasan" dalam Jurnal Pemikiran Sosiologi, Vol.2, No.2 (2013), h. 1-10. 
Poin penting dari politik multikulturalisme ini adalah hadirnya ketidakadilan dari berbagai aspek baik dari aspek ras, kulit, etnis, bahkan bahasa. Apa yang terjadi di berbagai belahan dunia lain, politik multikulturalisme diperankan dengan berbagai bentuk perlawanan. Gerakan-gerakan anti rasisme setidaknya menjadi contoh konkret dari politik multikulturalisme. Oleh karena itu, penulis ingin mengawali politik multikulturalisme dengan mengurai politik rasisme. Politik rasisme ini adalah elemen penting dari politik multikulturalisme. Oleh karena itu menarik untuk dieksplorasi lebih jauh bagaimana ras dan rasisme bekerja dalam berbagai dimensi kehidupan.

\section{Ras dan Rasisme}

Salah satu perdebatan penting dalam politik rasisme adalah sejauhmana perannya dalam politik multikulturalisme. Seperti diakui oleh Ben Pithcer, bahwa peran politik rasisme seringkali tidak diperhitungkan dalam peta politik multikulturalisme. Padahal menurutnya, politik rasisme sama pentingnya dengan politik anti rasisme. Dengan kata lain, hadirnya politik rasisme menjadi cikal bakal munculnya politik antirasisme. Begitupula sebaliknya, politik anti-rasisme tidak muncul kalau tidak diawali politik rasisme. Relasi keduanya bisa disebut binary opposition. ${ }^{6}$

Terminologi rasisme sendiri disadur dari istilah Inggris yaitu racism yang memiliki dua akar kata race dan ism. Dalam kamus Britannica, racism sering juga disebut racialism yang bermakna kepercayaan dimana manusia terbagi kepada dua tanda besar, baik dari segi fisik maupun dari segi kepribadian. Melalui dua segi ini, manusia seringkali menggunakannya untuk menguasai yang lain atau superior terhadap suku lain. Term ini juga seringkali dipakai dalam konteks politik, ekonomi, untuk melakukan diskriminasi atas nama superioritas suku. Pada titik inilah, konteks rasialisme menemukan relevansinya. Jadi, ras dalam konteks ini tidak hanya pada persoalan perbedaan fisik tetapi poin penting bagaimana ras itu dipakai sebagai argumen untuk menghegemoni ras yang lain. ${ }^{7}$

Dalam kamus lain, seperti yang diungkap dalam Merriam Webster, bahwa racism itu adalah sebuah kepercayaan dimana persoalan ras itu menjadi penentu

\footnotetext{
${ }^{6}$ Ben Pitcher, Politics of Multiculturalism: Race and Racism in Contemporary Britain (UK: Palgrave Macmillan, 2009), h. 11.

${ }^{7}$ Audrey $\quad$ Smedley, "Racism" dalam Encyclopedia Britannica, https://www.britannica.com/topic/racism diakses 21 Oktober 2021.
} 
fundamental dalam memperlakukan manusia dan perbedaan ras itu bisa memproduksi superioritas ras di atas yang lain. ${ }^{8}$

Term racism ini kemudian diinternalisasi ke dalam bahasa Indonesia yang kemudian disebut rasisme. Term ini telah menyeruak di ruang-ruang ketidakadilan seiring dengan munculnya politik rasisme dimana munculnya satu ras yang dominan dalam satu negara menghegemoni ras yang lain. Dengan kata lain, dalam hubungan kewarganegaraan, dominasi dan eksistensi ras tertentu mengalahkan eksistensi ras lain menjadi pemicu munculnya politik anti-rasisme. Jika ditelusuri lebih jauh, hegemoni rasisme ini muncul karena kentalnya politik praktis yang mewarnai hubungan kewarganegaraan. Politik yang ingin menguasai ruang-ruang publik baik dalam konteks pemerintahan maupun pada lembaga-lembaga politik.

Kecenderungan di atas pada prinsipnya dimiliki oleh setiap ras terlepas darimana asal ras tersebut. Argumen inilah yang menjadi alasan bagi Ben Pithcer bahwa perlawanan anti-rasis adalah perlawanan imaginer. Perlawanan yang tidak akan melahirkan hasil yang maksimal karena dilandasi dengan kepentingan tertentu. Artinya perlawanan tersebut hanya melahirkan politik rasisme baru. Politik anti-rasis ini muncul jika ras tersebut masih menjadi inferior, di bawah tekanan ras tertentu. Namun ketika kelompok anti-rasis mengambil alih kekuasaan, maka muncul rasisme baru. Disinilah letak dilematisnya ketika politik anti-rasis ini dijadikan sebagai ideologi untuk melawan ketidaksetaraan dan ketidaksederajatan, namun pada akhirnya justru menjadi kekuatan baru yang mendukung ketidakadilan tersebut. Landasan inilah yang menjadi urgen untuk direview lebih jauh terutama dalam hubungannya dengan politik multikulturalisme. ${ }^{9}$ Artinya, dalam penerapan anti-rasist ini seringkali mempergunakan double standar (standar ganda). Logika double standar ini mirip dengan implemetasi demokrasi, dimana negara-negara yang selama ini menjadi pusat pembelajaran demokrasi atau setidaknya dijadikan sebagai kiblat demokrasi, tetapi pada saat yang bersamaan, justru mereka sendiri yang menginjak-injak demokrasi.

Ras adalah warisan natural dalam kehidupan manusia. Artinya, sebuah takdir yang tidak bisa dibantahkan bahwa manusia itu lahir sudah ditentukan berada di ras

\footnotetext{
${ }^{8}$ Merriam-Webster.com Dictionary, "Racism" dalam https://www.merriamwebster.com/dictionary/racism diakses 10 Oktober 2021.

${ }^{9}$ Ben Pitcher, Loc.Cit.
} 
mana. Manusia tidak memiliki kemampuan untuk lahir di ras tertentu. Dengan kata lain, ras itu adalah takdir, tetapi rasisme itu adalah kontruksi yang dibangun oleh manusia atau sekelompok komunitas. Penjelasan ini diurai oleh Tonya Maria Golosh-Boza dalam bukunya Race and Racisms: A Critical Approach. Ia mengatakan bahwa ras itu mengalami evolusi yang kemudian menjadi rasialisme. Ras pada dasarnya berkaitan dengan aspek biologis manusia, tetapi karakter dari ras itu adalah konstruksi manusia.

Buku di atas termasuk referensi otoritas dalam kaitannya dengan politik multikulturalisme yang menjelaskan bagaimana ras itu berkembang menjadi sebuah ideologi. Dalam catatan Celeste Atkins yang mencoba mereview buku tersebut, ia mengatakan bahwa buku race and racism adalah bukti nyata bahwa persoalan rasialisme itu menjadi tema penting dalam konteks kehidupan bernegara. ${ }^{10}$ Dalam penjelasannya, bahwa rasialisme itu bisa terjadi dimana saja, bahkan di Eropa sekalipun sejak perang dunia, persoalan ras telah mengemuka kemudian membentuk satu ideologi yang berperan penting dalam kolonialisme dan imperialisme. Beberapa negara yang menjadi sampel korban dari sisi rasialisme dalam kehidupan bernegara seperti di Eropa, Amerika Serikat, Amerika Latin, Asia, Australia, dan Afrika. Masih segar dalam memori kolektif bagaimana ras Eropa telah membentuk pandangan dunia terkait keutamaannya. Begitupula, dominasi rakyat kulit putih (White Anglo Saxon) menghegemoni ras lain di Amerika juga telah menodai perjalahan hidup manusia. Di Amerika Latin, terutama di Meksiko juga tidak luput dari soal rasialisme.

Kasus rasialisme ini juga melanda negara-negara di Asia, termasuk di dalamnya Asia Tenggara. Dalam konteks Indonesia, yang menjadi salah satu negara di Asia Tenggara, soal rasialisme juga seringkali menjadi "hantu" yang setiap saat bisa membuat negara ini ketakutan dengan trauma issu rasialisme. Kasus kampanye AntiAhok dalam konteks pemilihan Gubernur DKI Jakarta beberapa tahun lalu telah mencederai perjalanan demokrasi bangsa ini. Resistensi Ahok menjadi gubernur oleh warga Jakarta dilandasi ras Ahok yang kebetulan memiliki garis keturunan China. Perbedaan ras yang tadinya tidak berimplikasi apapun dalam konteks bernegara, tiba-

${ }^{10}$ Celeste Atkins, "Book Review: Race and Racisms: A Critical Approach" dalam Teaching Sociology, Vol. 44, No. 2 (2016), h. 128-130. 
tiba menjelma menjadi satu ideologi yang menggerakkan warga untuk terlibat secara politik untuk tidak mendukung calon yang berasal dari ras China. ${ }^{11}$

Menariknya, pemanfaatan rasisme sebagai bagian dari kampanye politik tersebut ternyata berhasil memprovokasi warga Jakarta untuk tidak memilih calon dari ras tersebut. Artinya, dalam konteks politik praktis, faktor ras ini memegang peran penting untuk dijadikan alasan untuk memilih dan tidak memilih calon tertentu dalam konteks pesta politik. Pada titik ini, maka wajar kalau politik rasialisme ini sering dipakai oleh politisi-politisi dalam rangka mencapai agenda politik mereka. Wacana politik rasialisme ini pada prinsipnya mirip dengan politik identitas. Identitas yang terdiri dari warna kulit, etnis, bahasa dibungkus dalam satu paket demi meraih kepentingan politik sepihak.

Persoalan rasis ini juga seringkali menjadi problem serius dalam dunia olahraga, terutama pada olahraga sepak bola. Issu ini menyeruak di berbagai media-media asing dikaitkan dengan tindakan rasis beberapa pemain sepak bola yang menghakimi sesama pemain atas nama ras. Bahkan tindakan rasis ini tidak hanya pemain yang kemudian menjadi korban, tetapi para pelatih, manager, dan semua yang terlibat dalam sepak bola berpotensi menjadi obyek dari rasisme. Dalam satu artikel panjang yang ditulis oleh Jonathan Liew, seorang wartawan sepakbola, ia mengatakan bahwa dunia sepakbola Inggris itu dipenuhi dengan issu rasisme dan kebencian. Menurutnya, kasus-kasus rasisme di Inggris diibaratkan siklus yang setiap saat bisa memunculkan tindakantindakan rasis dalam berbagai bentuk. Para pemain sepakbola yang kebetulan berkulit hitam, seperti para pemain Manchester United, sebutlah Marcus Rashford, Paul Pogba seringkali menjadi kekerasan tindakan rasis tersebut. ${ }^{12}$

Jika dipotret secara sekilas, bahwa persoalan tensi yang tinggi dan iklim kompetisi yang kuat antara klub dan pemain sepak bola bisa menjadi salah satu faktor munculnya tindakan rasis sesama pemain sepak bola dengan cara verbal. Kasus kekerasan sepak bola ini paling sering ditunjukkan dengan bahasa atau kata-kata yang menyulut rasisme. Dengan massifnya platform media sosial saat ini, maka bentuk

\footnotetext{
${ }^{11}$ Tracey Yani Harjatanaya \& Chang-Yau Hoon, "Politics of Multicultural Education in PostSuharto Indonesia: a Study of the Chinese Minority" dalam Compare: A Journal of Comparative and International Education, Vol. 50, No. 1 (2020), h. 18-35.

${ }^{12}$ Jonathan Liew, "English football is consumed by racism and hatred. Can the cycle be broken?" dalam https://www.theguardian.com/football/2021/feb/08/english-football-is-consumed-by-racism-andhatred-can-the-cycle-be-broken diakses 10 Oktober 2021.
} 
tindakan rasis seringkali dibentuk melalui media-media sosial tersebut, seperti facebook, twitter, instagram. ${ }^{13}$

Saat sekarang ini, perilaku rasis dalam dunia sepakbola tidak lagi menjadi issu personal antara satu pemain dan pemain lainnya, tetapi sudah menjadi perhatian serius bagi dunia global. Bahwa ketika dunia semakin mengenal demokrasi, teori-teori multikulturalisme bermunculan, pemihakan terhadap hak-hak azasi manusia disuarakan pada panggung-panggung internasional, tetapi kasus rasisme dan kebencian antara satu dengan yang lainnya masih sering mewarnai perjalanan bangsa yang dijadikan sebagai rujukan sosial moral.

Namun demikian, usaha-usaha untuk menghentikan kasus rasisme ini sudah banyak digalakkan di negara-negara maju, termasuk UK. Bahkan Pangeran William juga ikut protes terhadap maraknya kasus-kasus rasis yang melanda negaranya dengan salah satu cuitannya sebagaimana berikut:

"We all have a responsibility to create an environment where such abuse is not tolerated, and those who choose to spread hate and division are held accountable for their actions. That responsibility extends to the platforms where so much of this activity now takes place,"14

Cuitan pangeran di atas mengindikasikan bahwa persoalan ini begitu serius dalam dunia kehidupan nyata yang tidak bisa ditoleransi dengan alasan apapun. Semua menjadi tanggung jawab bagaimana menciptakan lingkungan atau atmosfer yang toleran terhadap perbedaan. Perlawanan yang serius terhadap tindakan rasis sekarang ini yang banyak dituangkan di media-media sosial membuat pemilik media sosial seperti facebook atau instagram juga ikut mengupdate statusnya sebagaimana berikut:

"There is no place for racism on Instagram and we are committed to removing it when we find it. We know there is more to do and we will continue to work closely with clubs, players and football authorities to investigate instances of discrimination and collectively tackle this issue." 15

Selain itu, pemilik twitter juga ikut mencuit dengan menyampaikan pesan menohok kepada seluruh pelaku tindakan rasis. Ia mengatakan "bahwa tidak ada tempat

\footnotetext{
${ }^{13}$ Dan Roan, "Is football's racism battle being lost on social media?" dalam https://www.bbc.com/sport/football/55887106 diakses 11 Oktober 2021.

${ }^{14}$ Ibid.

${ }^{15}$ Ibid.
} 
bagi pelaku tindakan rasis dalam pelayanan kami, dan jika kami menemukan pelaku tindakan rasis, itu sudah melanggar aturan twitter, dan kami tidak segan-segan melakukan aksi-aksi legal kepada para pelanggar ini”. Kegelisahan dan kegalauan para pemilik media sosial di atas tentu ditunjukkan dalam kerangka perlawanan bersama terhadap tindakan rasis tersebut dimana media sosial mereka seringkali dijadikan panggung bagi para pelaku rasis tersebut.

Suara perlawanan para pemilik media sosial tersebut juga diback up dengan lahirnya regulasi yang memberatkan bagi para pelanggar tersebut. Mereka sudah memberikan hukuman dan sangsi denda bagi siapa saja pelanggar aturan tersebut. Bahkan denda yang sangat besar menanti para pelanggar tersebut. Bagi Jonathan, menghentikan kasus rasisme tidak hanya persoalan sangsi atau denda yang tinggi, tetapi pentingnya edukasi yang panjang serta didikan moral yang mengakar, ditambah lingkungan kondusif, menjadi salah satu pekerjaan rumah bagi para pemangku kepentingan (stakeholder).

Barangkali inilah yang menjadi alasan dalam setiap pertandingan sepakbola pada tingkat dunia, selalu diawali dengan bentangan kain lebar yang bertuliskan fair play and say no to racism dan diarak ke tengah lapangan. ${ }^{16}$ Bentangan ini tentu tidak hanya dimaknai hanya sekadar ritual seremoni pertandingan, tetapi bentangan ini memiliki pesan mulia bahwa kebencian model apapun terhadap sesama, tidak boleh hadir dalam kehidupan manusia, termasuk dalam olah raga yang menjunjung tinggi semangat fairplay dan sportivitas. Bentangan kain juga bisa dimaknai bahwa persoalan rasisme ini belum berakhir dalam kehidupan nyata. Secara teoretis, tindakan rasis adalah musuh bersama, tetapi dalam kehidupan praktis, tindakan ini masih menjadi ancaman besar bagi dunia olah raga, bahkan secara umum kepada dunia global.

Bentangan kain yang bertuliskan fair play and say no to racism mungkin belum dianggap cukup oleh dunia sepakbola, terutama untuk beberapa negara Eropa dimana tindakan rasis seperti UK. Mereka memunculkan berbagai banner yang dimunculkan di media-media on-line yang berbunyi let's kick racism out of football. Pesan ini tentu berbeda dengan yang sebelumnya yang bernada perintah. Pesan terakhir ini menunjukkan bahwa memerangi tindakan rasis adalah tanggung jawab bersama. Tidak

${ }^{16}$ Christos Kassimeris, Anti-Racism in European Football: Fair Play for All (Lanham : Lexington Books, 2009), h. 35. 
cukup hanya menanti regulasi pemerintah untuk melawan tindakan tersebut. Semua ini harus berangkat dari grass root (lapisan bawah) secara bersama-sama melakukan edukasi atau pendidikan positif terhadap anak-anak sampai kepada umur dewasa.

Beberapa kasus di atas hampir semuanya berlokus di UK. Kondisi ini menjadi tantangan tersendiri bagi politik multikulturalisme di Eropa. Barangkali ini juga yang mendasari pengertian multikulturalisme masih menjadi kegelisahan dan kebingungan bagi sebagian orang termasuk yang diekspresikan oleh Tony Blair, mantan Perdana Menteri Inggris, sebagaimana kutipan berikut: "I never knew, although I use the term myself occasionally, quite what people mean when they talk about multiculturalism"17

Kegelisahan Tony Blair di atas bisa saja berangkat dari realitas sosial kemasyarakatan di UK yang secara internal masih menyisakan masalah serius dalam hubungan kewarganegaraan. Kasus terbaru yang telah menjadi headlines media-media mainstream terutama yang berlokus di UK adalah keluarnya Pangeran Harry dari daftar keluarga kerajaan Inggris akibat adanya klaim tindakan rasis di internal keluarga kerajaan. ${ }^{18}$ Kasus ini tentu menjadi sejarah baru dan sekaligus menjadi preseden buruk bagi keluaga kerajaan yang selama ini terkenal dengan loyalitas dan keberpihakannya kepada nilai-nilai multikulturalisme. Merujuk kepada beberapa momen wawancara Megan Markle yang disiarkan di berbagai TV Show mainstream, terungkap bahwa alasan utama Megan Markel keluar dari anggotan royal kerajaan karena kekerasan verbal (rasisme) yang diterimanya akibat hubungan darah Markel berkaitan dengan warga keturunan kulit hitam. ${ }^{19}$

Multikulturalisme sebagai sebuah ideologi perjuangan dalam mendapatkan kesetaraan dan kesederajatan akan mendapatkan batu sandungan jika politik yang diberlakukan adalah politik yang tidak berpihak kepada semua elemen. Tindakantindakan rasis sebagaimana digambarkan pada uraian di atas adalah sebagian dari batu sandungan yang mencederai perjuangan multikuturalisme sebagai sebuah langkah politik. Politik multikulturalisme memiliki misi suci untuk menciptakan keadilan yang berlaku untuk semua orang yang bebas dari tindakan-tindakan rasialis dan diskriminatif.

\footnotetext{
${ }^{17}$ Ben Pitcher, Op.Cit., h.19.

${ }^{18}$ Adela Suliman, "Meghan and Harry's interview lays bare racism in the U.K., Black Britons say” dalam https://www.nbcnews.com/news/world/meghan-harry-s-interview-lays-bare-racism-u-kblack-n1260159 diakses 11 Oktober 2021.

${ }^{19}$ https://www.youtube.com/watch?v=5x7_5c6Y_dI
} 
Dalam konteks ini, politik multikulturalisme sejalan dengan visi besar dari satu disiplin ilmu culture studies (studi-studi budaya) yang menfokuskan kepada perlawanan dan pendampingan budaya-budaya sub-alter yang selama ini terpinggirkan. Kasus rasialisme di atas adalah bentuk peminggiran terhadap ras-ras yang dianggap inferior. Jadi, dalam konteks interaksi antara satu budaya atau ras antara satu dengan yang lainnya terjadi ketidakseimbangan atau ketidakadilan.

Dalam studi culture studies, hubungan yang setara ini diistilahkan dengan hubungan dipandang dan memandang. Barat memandang timur, begitupula sebaliknya, timur memandang barat. Atau barat memandang dirinya sendiri, dan timur juga memandang barat. Hubungan timbal balik ini penting dalam konteks culture studies dengan pertimbangan bahwa kemungkinan terjadinya distorsi dalam berbagai kajian bisa diminimalisir. Karena obyek culture studies begitu luas, maka bagian ini menjadi tema penting untuk dibahas pada uraian berikut dengan mengaitkannya dengan aspek budaya tinggi dan budaya rendah yang menjadi concern utama dari culture studies.

\section{Multikulturalisme dan Culture studies}

Sebagai bentuk politik multikulturalisme, studi-studi tentang budaya urgen untuk dieksplorasi lebih jauh. Secara historis, culture studies juga menjadi bagian dari teori kritis sebagaimana multikulturalisme terutama pengamatannya terhadap fenomena munculnya hegemoni satu budaya atas budaya lainnya. Tampaknya dominasi budaya telah menjadi tema sentral bagi para sarjana modern akibat adanya hubungan yang tidak berimbang baik dalam skala kecil maupun dalam konteks yang lebih luas.

Sebelum menjelaskan lebih jauh makna culture studies dalam hubungannya dengan politik multikulturalisme, ada baiknya menyimak pengertian culture (budaya) itu sendiri. Berikut pengertian budaya yang dikutip dari Storey:

"The "shared meanings we make and encounter in our everyday lives (....) the practices and processes of making meanings with and from the "texts" we encounter in our everyday lives".

Pengertian budaya di atas menggambarkan bahwa budaya adalah makna-makna dalam kehidupan yang merupakan hasil dari kesepakatan-kesepakatan antara seseorang dengan yang lainnya terkait dengan praktek atau tradisi sehari-hari yang berasal dari teks-teks baik itu tertulis maupun secara lisan. Jadi pengertian budaya ini mempertegas 
bahwa budaya itu tidak boleh dipaksakan kepada yang lain karena ia merupakan agreement (kesepakatan). Poin ini akan menjadi tema yang relevan terkait dengan multikultualisme. Untuk memperluas pengertian budaya ini, penulis akan mengutip pengertian lain tentang budaya sebagaimana berikut:

"An "ensemble of beliefs and practices that function as a pervasive technology of control, a set of limits within social behavior must be contained, a repertoire of models to which individuals must conform."

Pengertian di atas menempatkan budaya sebagai seperangkat kepercayaan dan praktek yang berfungsi sebagai alat control untuk membatasi intervensi teknologi. Budaya juga dipahami sebagai batasan dimana didalamnya harus diisi dengan tindakan sosial yang menjadi representasi dari teori tersebut. Hal ini penting dipahami karena budaya itu terkait praktek dalam kehidupan yang menjadi model kehidupan dimana seorang individu tidak memiliki pilihan.

Dua pengertian budaya di atas setidaknya bisa mendemonstrasikan bahwa filosofi budaya itu adalah apresiasi terhadap keragaman dan diversifikasi. Budaya adalah alat control agar seorang individu tidak terjebak kepada lajunya teknologi yang membuatnya kehilangan originalitas budayanya. Dan yang lebih penting bahwa budaya itu harus dibagi kepada yang lainnya, budaya tidak cukup kalau hanya seorang individu yang mempercayai dan mempraktekkannya. Ia adalah hasil dari kesepakatan kolektif beberapa individu yang membentuk komunitas dan mempraktekkan praktek tersebut dalam kurung waktu yang lama.

Multikulturalisme dan culture studies memiliki hubungan yang erat dengan pertimbangan bahwa keduanya membahas obyek yang sama yaitu budaya. Argumen inilah yang mendasari mengapa dua tema ini dimasukkan dalam tema politik multikulturalisme. Sebagai sebuah gerakan perlawanan terhadap kesetaraan, multikulturalisme memerlukan strategi untuk mencapai visi dan cita-citanya. Pada titik inilah menurut penulis, kehadiran culture studies yang didalamnya banyak disinggung teori-teori gerakan menemukan relevansinya.

Jika dibandingkan dengan multilkulturalisme, wilayah kajian dari culture studies lebih luas. Menurut Raymond Williams (1921-1988), salah satu pakar culture studies yang juga telah mempopulerkan istilah ini, ia mengatakan bahwa obyek culture studies mencakup berbagai aspek seperti organisasi produksi, struktur keluarga, hingga struktur 
lembaga yang mengekspresikan atau mengatur relasi sosial dan ragam bentuk komunikasi yang menjadi ciri dalam masyarakat luas. ${ }^{20}$

Jika ditelusuri sejarah munculnya culture studies, maka kemunculannya beririsan dengan multikulturalisme yaitu pada tahun 1960-an. Hanya saja, menurut penelusuran penulis, culture studies ini lebih terkonsentrasi pada pandangan terhadap budaya dalam kerangka teoretis. Dengan kata lain, studi budaya ini mirip dengan orientasi lain dari multikulturalisme yaitu sebagai sebuah obyek akademik sebagaimana dijelaskan pada bab sebelumnya. Sebagai wacana akademik, multikulturalisme juga menjadi obyek perdebatan panjang ahli-ahli ilmu sosial. Ia ditempatkan sebagai bagian penting dari disiplin ilmu sosial terutama dalam studi gerakan-gerakan sosial yang mulai berkembang pada 1960-an.

Pengembangan culture studies sebagai satu disiplin ilmu sosial pada gilirannya memerlukan pendekatan interdisipliner dengan pertimbangan wilayah kajiannya yang luas. Adapun visi utama culture studies tidak bisa dilepaskan dari peran institusiinstitusi sosial dalam mempertajam dan memperluas budaya sebagai entitas penting dalam meningkatkan pemberdayaan sosial manusia. Culture studies sendiri pertama kali muncul di Inggris pada akhir 1950-an dan berkembang secara internasional pada tahuntahun berikutnya, termasuk di Amerika dan Australia. ${ }^{21}$

Kehadiran culture studies juga ditandai dengan hadirnya Center for Contemporary Culture studies di Universitas Birmingham pada tahun 1964 yang memunculkan beberapa sarjana yang nantinya menjadi ikon dari culture studies. Antara lain Richard Hoggart, Stuart Hall dan Raymond Williams. Berkat kontribusi dari sarjana-sarjana tersebut, culture studies berkembang menjadi satu disiplin ilmu yang semakin mandiri dan established di berbagai universitas terkemuka. Meskipun demikian, embrio lahirnya culture studies pada prinsipnya sudah disuarakan oleh beberapa pemikir Eropa yang muncul sejak pasca perang dunia pertama seperti Sigmund Freud, Karl Marx, Friedrich Engels, Roland Barthes, Pierre Bourdieu, Michel Foucault, Jacques Lacan, Mikhail Bakhtin, Ferdinan de Saussure. Semua tokoh-tokoh

\footnotetext{
${ }^{20}$ Akhyar Yusuf Lubis, Op.Cit., h. 51.

${ }^{21}$ The Editors of Encyclopaedia Britannica, "Cultural Studies" dalam Encyclopedia Britannica, https://www.britannica.com/topic/cultural-studies diakses 12 Oktober 2021.
} 
ini telah meletakkan fondasi culture studies sehingga bisa berkembang seperti sekarang ini. $^{22}$

Pengaruh dari culture studies ini belakangan memberi pengaruh yang besar terhadap disiplin ilmu lain seperti sosiologi, antropologi, historiografi, kajian literature, filsafat dan kritisisme. Namun tema sentral dari pengaruh culture studies ini adalah persoalan ras atau etnik, kelas dan gender. ${ }^{23}$ Yang disebut terakhir ini menarik untuk dicermati karena salah satu materi penting dari politik multikulturalisme adalah gerakan feminism yang memperjuangkan kesetaraan dan kesederajatan antara laki-laki dan perempuan. $^{24}$

Dalam beberapa referensi terkait dengan politik multikulturalisme, poin-poin penting yang menjadi tema pembicaraan adalah gesekan-gesekan yang terjadi antara satu budaya dengan budaya lainnya. Poin terakhir ini juga menjadi obyek kajian dari culture studies, terutama dalam konteks budaya besar dan budaya pinggir atau dalam istilah culture studies yaitu subaltern. Yang disebut terakhir ini adalah diskursus penting dalam culture studies. Pertarungan antara kelas kulit hitam dengan kulit putih juga menjadi issu penting dalam multikulturalisme dan culture studies.

Istilah subalter sendiri menjadi terminologi penting dalam wacana culture studies. Gayatri Chakravory Spivak (1942), seorang pemikir India, yang mempopulerkan istilah subaltern ini. Ia menulis satu artikel yang fenomenal terkait tema ini dengan judul "can subaltern speak? Spivak menjelaskan bahwa terminologi ini merujuk kepada adanya populasi yang berbeda-beda baik dari segi pandangan politik, ekonomi, sosial budaya kemudian harus tunduk kepada otoritas satu kelompok yang hegemonik. Jadi, kelompok sosial atau politik yang minoritas tersebut seakan-akan dipresentasikan oleh kelompok mayoritas tersebut yang dianggap mewakilkan suara atau eksistensi mereka. Dengan kata lain, suara sub-alter tertutupi oleh suara otoritas. ${ }^{25}$

Konsekuensinya, kelompok subaltern tidak pernah mendapatkan kesempatan untuk berbicara menyuarakan perlawanan mereka karena diasumsikan menerima semua kebijakan publik meskipun kebijakan tersebut pada prinsipnya tidak berpihak kepada

\footnotetext{
${ }^{22}$ https://bowiestate.libguides.com/c.php?g=442217\&p=3014989

${ }^{23}$ The Editors of Encyclopaedia Britannica, Loc.Cit.

${ }^{24}$ Ben Pitcher, Op.Cit., h iv

${ }^{25}$ Gayatri Chakravorty Spivak, "Can the Subaltern Speak?" dalam Cary Nelson \& Lawrence Grossberg (eds.), Marxism and the Intepretation of Culture (Basingstoke: Macmillan Education, 1988), h.
} 66-111. 
mereka. ${ }^{26}$ Inilah yang menjadi kegelisahan seorang Spivak dalam mengamati fenomena masyarakat baik di India maupun di negara-negara lain. Suara kelompok subaltern ini tenggelam dan tertutupi oleh suara mayoritas

Dalam culture studies, terdapat gerakan-gerakan politik yang tidak hanya terkait dengan budaya, tetapi agama yang memainkan peran penting dalam menghegemoni agama-agama lain juga menjadi issu yang hangat diperbincangkan. Hegemoni agamaagama besar dunia terhadap agama-agama "pinggiran" banyak ditulis dalam literatureliteratur klasik. Agama dalam konteks ini menjadi alat politik untuk menguasai dan mengkoptasi pemeluk agama lain dalam secara struktural dan kultural. Fenomena ini kemudian disebut sebagai praktek politisasi agama. Agama dalam konteks ini menjadi alat untuk menguasai komunitas lain bahkan agama seringkali digiring untuk menjadi stempel untuk melegitimasi kebijakan-kebijakan yang tidak berpihak ke publik.

Kepincangan-kepincangan di atas terkait politisasi agama ataupun budaya telah diisi oleh cultural studies dalam rangka mencapai kesetaraan. Berikut beberapa prinsip yang menjadi panduan dalam memahami culture studies: 1) Realitas adalah konstruksi social; 2) Identitas adalah konstruksi sosial; 3) Kepercayaan atau keyakinan berlandaskan persepsi terhadap realitas; 4) Masyarakat ditandai dengan perjuangan untuk kekuasaan; 5) Kode-kode budaya menciptakan identitas untuk pencipta dan penerima. $^{27}$

Merujuk kepada beberapa prinsip cultural studies di atas, bahwa realitas dan identitas adalah kontruksi sosial maka teori culture studies juga tidak bisa dilepaskan dari konstruksi sosial. Apa yang dipahami sebagai realitas budaya dalam konteks culture studies tentu tidak genuine karena tidak bisa dilepaskan dari teori dan rencana manusia. Manusialah yang menjadi aktor dalam merekonstruksi budaya tersebut.

Disinilah seringkali menjadi dilematis ketika manusia sendiri tidak bisa melepaskan diri dari sifat subyektifitasnya terhadap budaya. Disadari atau tidak, setting sosial dan ruang dimana manusia berkecimpung akan memberi pengaruh yang besar terhadap konstruksi yang dibangunnya. Hal ini tentu beralasan dengan pertimbangan bahwa teks-teks itu lahir tidak di ruang hampa melainkan produk-produk tersebut adalah konstruksi manusia yang bisa benar dan bisa juga keliru. Seorang penulis adalah

\footnotetext{
${ }^{26}$ Ibid., h. 70.

${ }^{27}$ https://bowiestate.libguides.com/c.php?g=442217\&p=3014989
} 
anak dari zamannya. Begitulah kalimat yang pantas untuk kajian culture studies terkait kajian teks yang oleh Roland Barthes (Pemikir Perancis) disebutnya sebagai the death of the author (matinya sang pengarang). ${ }^{28}$

Konstruksi sosial sendiri adalah usaha manusia untuk membangun persepsi dan perspektif terkait realitas dan identitas budaya berdasarkan pengalamannya. Apa yang dipahami sebagai realitas dan identitas dalam culture studies pada prinsipnya hanya tafsir terhadap realitas tersebut, bukan realitas itu sendiri. Dengan kata lain, realitas itu sesuatu yang original dan natural, ia lepas dari conflict of interest (konflik kepentingan).

Problem cultural studies muncul ketika menempatkan realitas itu bukan pada tempatnya, atau salah memahami realitas itu sendiri. Tafsir terhadap realitas sosial kemasyarakatan dijadikan realitas yang melandasi teori yang ada. Misalnya, adanya budaya tinggi dalam kelas sosial kemasyarakatan yang menjadi pembeda dengan budaya lain. Sementara budaya lain dianggap sebagai budaya kelas kedua dalam kelas sosial. Culture studies dalam konteks ini menjadikan tema-tema tersebut sebagai bahan untuk melakukan perlawanan kepada ketidakadilan dan diskriminasi.

Sebagaimana dijelaskan di awal pembahasan bahwa wilayah kajian dari culture studies begitu luas, termasuk di dalamnya feminisme. ${ }^{29}$ Tema ini juga menjadi wilayah kajian serius dari culture studies mengingat bahwa adanya budaya partiarkhi (kebapakan) dalam relasi keluarga seakan menggambarkan sebuah realitas masyarakat yang genuine. Padahal jika merujuk kepada prinsip di atas, budaya kebapakan itu adalah konstruksi sosial yang bias gender yang menempatkan laki-laki (bapak) superior di atas perempuan (inferior).

Stigma bahwa perempuan adalah makhluk kelas kedua dalam masyarakat muncul akibat kekeliruan dalam memahami realitas itu sendiri. ${ }^{30}$ Mereka berasumsi bahwa posisi atau kedudukan laki-laki lebih tinggi daripada perempuan adalah realitas kehidupan yang tidak bisa ditolak. Dalam pemahaman mereka, perempuan harus tunduk dan patuh kepada norma dan ajaran tersebut. Perempuan dipercaya tidak memiliki kekuasaan untuk menolak status dan perannya sebagai “obyek" dari laki-laki.

\footnotetext{
28“The death of the author" adalah judul artikel yang ditulis oleh Roland Barthes (1915-1980), pada tahun 1967. Barthes mengkritik ideologi traditional yang menggabungkan antara keinginan penulis dengan teks atau literatur dalam menerjemahkan satu teks.

${ }^{29}$ Akhyar Yusuf Lubis, Op.Cit., h. 55.

${ }^{30}$ Nasaruddin Umar, Argumen Kesetaraan Gender (Jakarta: Paramadina, 1999), h. 321.
} 
Perempuan juga, bagi keyakinan sebagian orang, dianggap tidak bisa menjadi pemimpin dengan satu keyakinan bahwa perempuan lebih mendahulukan perasaan dan emosinya dibandingkan dengan akal atau nalarnya.

Ibaratnya, jika ada perempuan yang berjuang untuk mendapatkan kesetaraan dengan laki-laki, maka perempuan tersebut akan dilaknat dan tidak akan mendapatkan keberuntungan hidup. Padahal realitas sesungguhnya adalah kesetaraan dan kesederajatan dalam hal peran-peran sosial. Perbedaan-perbedan dari segi fisik adalah kemestian dan kelaziman yang tidak bisa dibantah. Dengan kata lain, perbedaan tersebut adalah takdir yang tidak bisa dilawan dimana manusia tidak memiliki pilihan-pilihan. Manusia tidak bisa memilih untuk menjadi laki-laki atau menjadi perempuan.

Culture studies dalam konteks ini bisa jadi menjadi sebuah gerakan perlawanan terhadap ketidakadilan perlakuan terhadap perempuan. Perlawanan ini menjadi bagian dari prinsip culture studies. Bahwa masyarakat dalam satu budaya akan terus berjuang melawan kekuasaan yang tidak berpihak ke masyarakat. Ciri ini cukup penting dalam menjelaskan culture studies yang akrab disebut sebagai masyarakat struggle of power. ${ }^{31}$ Perlawanan dalam konteks ini bisa mengambil bentuk secara beragam, seperti politik, ekonomi, budaya, bahkan intelektual sebagaimana yang diinginkan oleh Spivak di atas. Perlawanan politik dipresentasikan dengan keterlibatan kelompok-kelompok budaya untuk menjadi bagian penting dari pembuatan regulasi yang berpihak ke mereka.

Sikap perlawanan ini harus dihadirkan mengingat kebijakan tanpa kritik memberi kesan bahwa kebijakan tersebut sudah sesuai koridornya. Dengan kata lain, sikap silent terhadap kebijakan yang tidak pro terhadap kesetaraan bisa mengganggu stabilitas politik yang sehat dalam konteks kehidupan bernegara. Bersuara atau mengajukan sikap kritis terhadap segala kebijakan yang ada apalagi dalam posisi minoritas baik secara populasi maupun secara kualitas. Barangkali inilah yang diinginkan oleh Spivak, kelompok minoritas mampu bicara meskipun kesempatan sulit didapatkan. ${ }^{32}$

Regulasi kebijakan publik atau undang-undang yang pro terhadap kondisi dan keadaan mereka harus dihadirkan dalam bentuk action, tidak hanya menjadi pemanis kertas saja. Selain itu, sikap perlawanan yang cukup penting juga adalah mengawal

\footnotetext{
${ }^{31}$ https://bowiestate.libguides.com/c.php?g=442217\&p=3014989.

${ }^{32}$ Gayatri Chakravory Spivak, Op.Cit., h. 70.
} 
jalannya implementasi aturan. Dalam konteks pemerintahan, check and balance itu menjadi penyeimbang dalam kehidupan bernegara. Eksekusi undang-undang tersebut melalui kebijakan praktis adalah sesuatu yang esensial dalam kehidupan kewarganegaraan. Perlawanan ekonomi dilambangkan dengan memperkuat dan memberdayakan kekuatan atau sumber daya ekonomi lokal tanpa menerima sistem ekonomi kapitalistik global. Aspek ini penting dalam kerangka perlawanan ekonomi yang lambat laun akan meminggirkan kekuatan ekonomi lokal. Poin ini menjadi krusial mengingat berbagai budaya yang terpinggirkan ataupun dipinggirkan akibat tidak memiliki fondasi atau kekuatan ekonomi yang kuat.

Sebagai contoh konkret, pengalaman budaya kelompok bissu yang berlokus di Segeri, Kabupaten Pangkep, Provinsi Sulawesi Selatan. Bissu ini termasuk kelompok budaya unik dan tua yang sudah lama hidup dan mendiami beberapa tempat di daerah Sulawesi Selatan. Keunikannya terletak kepada perannya yang secara historis dipercaya sebagai penerjemah pesan-pesan yang datang dari langit sehingga bisa dipahami oleh makhluk yang ada di bumi, terutama manusia. Fungsi dan peran ini mirip dengan peran dewa Hermes dalam mitologi Yunani yang juga menjadi penerjemah tuhan yang memiliki bahasa langit sehingga bisa dipahami oleh manusia. Kalau dalam tradisi Islam, Hermes ini disimbolkan dengan peran Nabi Idris yang dalam sejarah kenabian disebut sebagai nabi pembelajar yang meletakkan budaya literasi dalam sejarah manusia sekaligus juga menjadi akar munculnya hermeneutika. Dewa Hermes inilah yang dinisbahkan kepada istilah hermeneutika yang secara literal dimaknai sebagai penafsiran atau interpretasi. ${ }^{33}$

Keunikan lain yang dimiliki oleh bissu ini adalah penampilannya yang mengkombinasikan jenis kelamin laki-laki dan perempuan. Sekilas penampilan mereka tidak berbeda dengan banci atau gay. Tetapi perannya di masyarakat begitu siginifikan terutama sebagai jembatan atau penghubung antara yang di langit dan di bumi. ${ }^{34}$

Eksistensi bissu yang unik di atas kemudian menjadi nilai jual (market value) bagi sebagian antropolog budaya untuk mengikut sertakan dalam berbagai festival budaya baik yang berskala nasional maupun internasional. Popularitas bissu pun

\footnotetext{
${ }^{33}$ Kamaruddin Hidayat, Agama Masa Depan: Perspektif Filsafat Perennial (Jakarta: Paramadina, 1997).

${ }^{34}$ Halilintar Latief, "Kepercayaan Orang Bugis di Sulawesi Selatan”. Disertasi. (Makassar: Antropologi UNHAS, 2005).
} 
terangkat dan semakin dikenal di dunia global yang juga berimplikasi kepada income bissu secara ekonomi juga mengalami peningkatan.

Konsekuensi dari popularitas ini adalah peragaan budaya yang sejatinya tidak untuk dipertontonkan, apalagi untuk kepentingan ekonomi, justru dijadikan sebagai cara peningkatan ekonomi bagi sekelompok bissu. Dengan kata lain, terjadi pergeseran fungsi ritual bissu yang sedarinya sebagai ritual suci untuk memperkuat relasi makhluk yang ada di bumi dengan yang di langit berubah menjadi media penguatan ekonomi atau terjadi komersialisasi. Bahkan dengan pergeseran fungsi ritual bissu ini melahirkan konflik internal dan berujung pemecahan antara satu bissu dengan bissu yang lain dikarenakan pembagian keuntungan ekonomi yang tidak merata. Ada dominasi internal yang terjadi di dalam komunitas bissu tersebut. ${ }^{35}$

Namun poin penting dari kasus bissu di atas adalah pentingnya kemandirian ekonomi internal bissu sehingga godaan atau tawaran dari luar yang memiliki missi komersialisasi budaya dapat terhindarkan. Maka bentuk perlawanan dari komunitas bissu ini adalah memberdayakan resourcesnya supaya bisa mapan dan kuat dari segi ekonomi. Spirit perlawanan ini yang harus dijaga oleh kelompok-kelompok budaya lokal sehingga tidak memunculkan kesan "culture for sale" (budaya diperjualbelikan).

Politik marketing budaya juga pada prinsipnya tidak hanya dialami oleh masyarakat bissu. Hampir semua budaya-budaya lokal mendapatkan tantangan yang sama ketika berhadapan dengan otoritas pemerintah. Contoh lain yang juga patut menjadi perhatian bersama adalah eksistensi Komunitas Karampuang di Sinjai. Komunitas ini memiliki keunikan budaya tersendiri dengan pola ritual yang relatif berbeda dengan budaya masyarakat Sinjai secara umum, terutama dalam menjaga relasinya dengan Tuhan dan alam. Hanya saja, apresiasi dan pelayanan pemerintah kepada mereka tidak dilandasi pada penghormatan kepada eksistensi budaya itu sendiri melainkan karena politik ekonomi. Nilai-nilai budaya mereka dikapitalisasi sehingga layak untuk dijual keluar dan sekaligus ajang untuk promosi daerah sebagai salah satu destinasi wisata di Sinjai. Politik komersialisasi menjadi salah satu alasan mengapa Komunitas Karampuang mendapat apresiasi dan pendampingan dari pemerintah.

${ }^{35}$ Imran, "Bissu: Genealogi dan Tegangannya dengan Islam" dalam Mimikri, Vol. 5, No. 1 (2019), h. 91-103. 
Beberapa kasus yang melanda komunitas budaya-budaya lokal terutama di Indonesia mencerminkan bahwa politik komersialisasi dagang telah menggiring makna genius dari budaya itu sendiri. Mereka tidak lagi menempatkan makna-makna kebajikan hidup menjadi sesuatu yang esensial dalam kehidupan budaya, atau menempatkan budaya sebagai seperangkat norma hidup, tetapi orientasinya bagaimana meningkatkan keuntungan secara ekonomi dari budaya tersebut. Dalam konteks Indonesia, barangkali ini juga menjadi latar belakang pergeseran studi budaya saat sekarang ini yang lebih diarahkan kepada aspek tourism atau wisata. Beberapa proyek penelitian budaya yang disponsori oleh pemerintah sekarang ini, khususnya kementerian pariwisata, yang akrab disebut dengan eco-tourism. ${ }^{36}$

Padahal, sejatinya, aspek budaya tersebut di atas harus diperkuat dengan aspek edukasi dan pemberdayaan yang idealnya di bawah naungan Kementerian Pendidikan dan Kebudayaan. Penempatan pendidikan berdampingan dengan kebudayaan sebenarnya berangkat dari filosofi bahwa kebudayaan harus dikembangkan melalui edukasi terutama pada nilai-nilai luhurnya. Nilai-nilai ini yang semakin lama semakin luntur pada kehidupan modern ini, terutama pada generasi millennial yang sudah tidak lagi mengenal budayanya. Mereka tercerabut dari akar budayanya yang orisinil. Pendidikan sendiri harus berbasis nilai-nilai luhur kebudayaan dimana toleransi, apresiasi, penghormatan antar sesama harus dibumikan dalam berbagai tingkat atau level pendidikan. Terkait dengan hal ini, penulis memandang bahwa pendidikan adalah wadah untuk menjaga nilai-nilai budaya sehingga bisa diwariskan dari satu generasi ke generasi berikutnya. Singkatnya, pendidikan memegang peran penting dalam menjaga dan melestarikan kebudayaan. ${ }^{37}$

Uraian di atas mempertegas relasi yang kuat antara multikulturalisme dan culture studies. Keduanya memiliki peran dan posisi yang kuat dalam menempatkan budaya sebagai elemen penting dalam menata hubungan individu dengan individu yang lainnya. Hubungan ini membentuk komunitas kuat jika di dasari dengan pembagian makna atau tradisi yang dilandasi dengan kesepakatan-kesepakatan bersama tanpa

\footnotetext{
${ }^{36}$ Term ecotourism didefinisikan sebagai "responsible traavel to natural areas that conserve the environment, sustains the well-being of the local people, and involves interpretation and education. Education is meant to be inclusive of both staff and guests" https://ecotourism.org/what-is-ecotourism/.

${ }^{37}$ Soumya Mary Mathews \& Arulsamy Savarimuthu, "Role of education in Transmitting Culture in Society" dalam https://www.researchgate.net/publication/339816271_Role_of_Education_in_ Transmitting_Culture_in_Society/citations diakses 12 Oktober 2021.
} 
hadirnya hegemoni satu individu dengan individu yang lainnya. Jika merujuk kepada definisi budaya di atas, maka sikap saling pengertian dan saling memahami antara satu dengan yang lainnya menjadi fondasi yang kuat dalam membentuk budaya yang kuat yang kemudian disebut dengan culture studies atau multikulturalisme. Apalagi memaknai multikulturalisme sebagai ideologi semakin memperkuat relasinya dengan culture studies.

Menurut penulis, politik multulkulturalisme harus berpijak kepada culture studies sebagai disiplin ilmu yang memiliki cakupan luas. Salah satu langkah strategis adalah dengan menggunakan pendekatan multidisipliner dalam melihat budaya. Politik multikulturalisme tidak semua bermakna destruktif, tetapi politik ini bisa diarahkan kepada makna konstruktif dalam melihat benang merah satu budaya dengan budaya lainnya, terutama kepada budaya-budaya yang selama ini termarginalkan karena kekuasaan yang tidak berpihak kepada mereka. Hegemoni budaya yang selama ini menghantui budaya-budaya pinggir atau istilah Spivak subaltern, melalui politik multikulturalisme, dapat dieliminir.

\section{Kesimpulan}

Politik multikulturalisme adalah bagian penting dari pembicaraan multikulturalisme. Tema ini tidak hanya mendiskusikan ide-ide perbedaan budaya sebagaimana yang diungkap dalam pluralisme, tetapi telah merambah kepada perjuangan dalam menerapkan multikulturalisme demi sebuah keadilan dan kesetaraan. Konteks inilah yang membagi multikulturalisme pada tiga lapisan, ideologi, wacana dan social studies. Perjuangan atas hak-hak tersebut erat kaitannya dengan irisan ideologi yang melahirkan gerakan atau perjuangan untuk perubahan tatanan sosial kemasyarakatan. Politik multikulturalisme tidak bisa dilepaskan dari politik rasisme dan politik budaya. Dua hal ini menjadi fondasi dalam menerapkan politik multikulturalisme. Selain itu, politik multikulturalisme ini juga harus dilandasi dengan keinginan menghadirkan pengakuan atas hak-hak individu di atas perbedaan-perbedan budaya, ras dan etnis. Pengakuan ini adalah tujuan dari politik multikulturalisme yang dikenal dengan politics of recognition. Dua hal penting yang seringkali berkaitan dengan politik pengakuan ini adalah rasisme dan culture studies. Perjuangan untuk mengikis ideologi rasisme dalam konteks kebangsaan adalah prioritas utama dalam 
politik multikulturalisme. Rasisme ini juga harus ditopang dengan kajian-kajian budaya terutama yang berkaitan dengan politik mayoritas versus politik minoritas. Culture studies tidak hanya berhenti pada kajian-kajian budaya yang terpinggirkan tetapi juga berisi perjuangan budaya pinggir menuju kepada budaya sentral yang diakui oleh otoritas politik dan budaya.

\section{DAFTAR PUSTAKA}

Lubis, Akhyar Yusuf. Pemikiran Kritis Kontemporer: Dari Teori Kritis, Culture studies, Feminisme, Post-Kolonial hingga Multikulturalisme. Jakarta: Raja Grafindo Persada, 2015.

Nye, Malory. "The Challenges of Multiculturalism" dalam Culture and Religion, Vol. 8, No. 2 (2007), h. 109-123.

Nugroho, Heru. "Multikulturalisme dan Politik anti Kekerasan" dalam Jurnal Pemikiran Sosiologi, Vol.2, No.2 (2013), h. 1-10.

Pitcher, Ben. Politics of Multiculturalism: Race and Racism in Contemporary Britain. UK: Palgrave Macmillan, 2009.

Atkins, Celeste. "Book Review: Race and Racisms: A Critical Approach" dalam Teaching Sociology, Vol. 44, No. 2 (2016), h. 128-130.

Harjatanaya, Tracey Yani \& Chang-Yau Hoon "Politics of Multicultural Education in Post-Suharto Indonesia: a Study of the Chinese Minority" dalam Compare: A Journal of Comparative and International Education, Vol. 50, No. 1 (2020), h. 18-35.

Kassimeris, Christos. Anti-Racism in European Football: Fair Play for All. Lanham: Lexington Books, 2009

Spivak, Gayatri Chakravorty. "Can the Subaltern Speak?” dalam Cary Nelson \& Lawrence Grossberg (eds.), Marxism and the Intepretation of Culture (Basingstoke: Macmillan Education, 1988), h. 66-111.

Umar, Nasaruddin. Argumen Kesetaraan Gender. Jakarta: Paramadina, 1999.

Hidayat, Kamaruddin. Agama Masa Depan: Perspektif Filsafat Perennial. Jakarta: Paramadina, 1997.

Latief, Halilintar. "Kepercayaan Orang Bugis di Sulawesi Selatan". Disertasi. Makassar: Antropologi UNHAS, 2005. 
Imran. "Bissu: Genealogi dan Tegangannya dengan Islam" dalam Mimikri, Vol. 5, No. 1 (2019), h. 91-103.

\section{Website}

Smedley, Audrey. "Racism" dalam Encyclopedia Britannica, https://www.britannica. com/topic/racism diakses 21 Oktober 2021.

Merriam-Webster.com Dictionary. "Racism" dalam https://www.merriamwebster.com/dictionary/racism diakses 10 Oktober 2021.

Liew, Jonathan. "English football is consumed by racism and hatred. Can the cycle be broken?" dalam https://www.theguardian.com/football/2021/feb/08/englishfootball-is-consumed-by-racism-and-hatred-can-the-cycle-be-broken diakses 10 Oktober 2021.

Roan, Dan. "Is football's racism battle being lost on social media?" dalam https://www.bbc.com/sport/football/55887106 diakses 11 Oktober 2021.

Suliman, Adela. "Meghan and Harry's interview lays bare racism in the U.K., Black Britons say" dalam https://www.nbcnews.com/news/world/meghan-harry-sinterview-lays-bare-racism-u-k-black-n1260159 diakses 11 Oktober 2021.

The Editors of Encyclopaedia Britannica. "Cultural Studies" dalam Encyclopedia Britannica, https://www.britannica.com/topic/cultural-studies diakses 12 Oktober 2021.

Mathews, Soumya Mary \& Arulsamy Savarimuthu, "Role of education in Transmitting Culture in Society" dalam https://www.researchgate.net/publication/ 339816271_Role_of_Education_in_ Transmitting_Culture_in_Society/citations diakses 12 Oktober 2021. 